\title{
Front Matter: Volume 7755
}

, "Front Matter: Volume 7755," Proc. SPIE 7755, Nanophotonic Materials VII, 775501 (2 November 2010); doi: 10.1117/12.880094

SPIE Event: SPIE NanoScience + Engineering, 2010, San Diego, California, United SPIE. States 


\title{
PROCEEDINGS OF SPIE
}

\section{Nanophotonic Materials VII}

\author{
Stefano Cabrini \\ Taleb Mokari \\ Editors
}

1-2, 4 August 2010

San Diego, California, United States

Sponsored and Published by

SPIE

Volume 7755

Proceedings of SPIE, 0277-786X, v. 7755 
The papers included in this volume were part of the technical conference cited on the cover and title page. Papers were selected and subject to review by the editors and conference program committee. Some conference presentations may not be available for publication. The papers published in these proceedings reflect the work and thoughts of the authors and are published herein as submitted. The publisher is not responsible for the validity of the information or for any outcomes resulting from reliance thereon.

Please use the following format to cite material from this book:

Author(s), "Title of Paper," in Nanophotonic Materials VII, edited by Stefano Cabrini, Taleb Mokari, Proceedings of SPIE Vol. 7755 (SPIE, Bellingham, WA, 2010) Article CID Number.

ISSN 0277-786X

ISBN 9780819482518

Published by

SPIE

P.O. Box 10, Bellingham, Washington 98227-0010 USA

Telephone +1 3606763290 (Pacific Time) · Fax +1 3606471445

SPIE.org

\section{Copyright (C) 2010, Society of Photo-Optical Instrumentation Engineers}

Copying of material in this book for internal or personal use, or for the internal or personal use of specific clients, beyond the fair use provisions granted by the U.S. Copyright Law is authorized by SPIE subject to payment of copying fees. The Transactional Reporting Service base fee for this volume is $\$ 18.00$ per article (or portion thereof), which should be paid directly to the Copyright Clearance Center (CCC), 222 Rosewood Drive, Danvers, MA 01923. Payment may also be made electronically through CCC Online at copyright.com. Other copying for republication, resale, advertising or promotion, or any form of systematic or multiple reproduction of any material in this book is prohibited except with permission in writing from the publisher. The CCC fee code is 0277-786X/10/\$18.00.

Printed in the United States of America.

Publication of record for individual papers is online in the SPIE Digital Library.

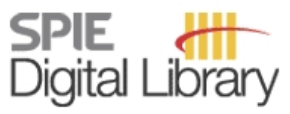

SPIEDigitalLibrary.org

Paper Numbering: Proceedings of SPIE follow an e-First publication model, with papers published first online and then in print and on CD-ROM. Papers are published as they are submitted and meet publication criteria. A unique, consistent, permanent citation identifier (CID) number is assigned to each article at the time of the first publication. Utilization of CIDs allows articles to be fully citable as soon they are published online, and connects the same identifier to all online, print, and electronic versions of the publication. SPIE uses a six-digit CID article numbering system in which:

- The first four digits correspond to the SPIE volume number.

- The last two digits indicate publication order within the volume using a Base 36 numbering system employing both numerals and letters. These two-number sets start with $00,01,02,03,04$, $05,06,07,08,09,0 A, 0 B \ldots 0 Z$, followed by 10-1Z, 20-2Z, etc.

The CID number appears on each page of the manuscript. The complete citation is used on the first page, and an abbreviated version on subsequent pages. Numbers in the index correspond to the last two digits of the six-digit CID number. 


\section{Contents}

$\checkmark$ Conference Committee

\section{SESSION 1 INFLUENCE OF THE SHAPE AND THE DOPANTS ON THE PROPERTIES OF NANOSTRUCTURES}

775502 The effect of $\mathrm{Pb}$ addition on the morphology of CdSe quantum dot [7755-01]

Y.-K. Kim, Y.-S. Cho, K. Chung, C.-J. Choi, Korea Institute of Materials Science (Korea, Republic of)

$775503 \mathrm{Eu}^{3+}$ as optical probe of the structure in amorphous and nanocrystalline $\mathrm{TiO}_{2}$ films prepared by sol-gel method [7755-02]

J. A. García-Macedo, G. Valverde-Aguilar, S. Flores-Duran, Univ. Nacional Autónoma de México (Mexico)

775505 Conductive dendrimers obtained by click chemistry [7755-04]

D. G. Lewis, Solar Redox Group (United States); L. B. Krasnova, The Scripps Research Institute (United States); P. J. Skinner, Solar Redox Group (United States) and The Scripps Research Institute (United States); V. V. Fokin, The Scripps Research Institute (United States)

\section{SESSION 2 OPTICAL PROPERTIES OF NANOSTRUCTURES}

775509 Band gap control of colloidal photonic crystal by hyperthermal neutral beam etching [7755-08]

Y.-S. Cho, Korea Institute of Materials Science (Korea, Republic of); G.-R. Yi, Chungbuk National Univ. (Korea, Republic of); J. H. Moon, Sogang Univ. (Korea, Republic of); B.-J. Lee, National Fusion Research Institute (Korea, Republic of); S.-M. Yang, Korea Advanced Institute of Science and Technology (Korea, Republic of); C.-J. Choi, Korea Institute of Materials Science (Korea, Republic of)

\section{SESSION 3 CONTROLLING THE OPTICAL PROPERTIES OF NANOSTRUCTURES BY FORMING TERNARY} MATERIALS (DOPING AND ALLOYING)

7755 OC Mid-infrared GalnSb quantum well laser structures: a comparison of their characterisation using photoluminescence, photo-modulated reflectance, and FTIR-based surface photovoltage spectroscopies [7755-11]

N. E. Fox, A. Andreev, Univ. of Surrey (United Kingdom); G. R. Nash, QinetiQ Ltd. (United Kingdom) and Univ. of Bristol (United Kingdom); T. Ashley, QinetiQ Ltd. (United Kingdom); T. J. C. Hosea, Univ. of Surrey (United Kingdom)

7755 OD Synthesis of highly luminescent Cd(Se,S) alloy nanocrystals [7755-12]

Y.-K. Kim, Y.-S. Cho, K. Chung, C.-J. Choi, Korea Institute of Materials Science (Korea, Republic of) 
7755 OE Effect of ammonia on luminescent properties of YAG:Ce ${ }^{3+}, \mathbf{P r}^{3+}$ nanophosphors [7755-13] J. Oliva, E. De La Rosa, L. A. Diaz-Torres, Ctr. de Investigaciones en Óptica, A.P. (Mexico); P. Salas, Univ. Nacional Autónoma de México (Mexico); A. Torres, Univ. Autónoma de Nuevo León (Mexico); O. Meza, Ctr. de Investigaciones en Óptica, A.P. (Mexico)

\section{SESSION 4 CHARGE DYNAMICS IN NANOSTRUCTURES}

$77550 \mathrm{~J}$ Inclusion of charge-charge and charge-phonon interactions in the presence of THz radiation [7755-18]

P. Sarker, Q. D. M. Khosru, Bangladesh Univ. of Engineering and Technology (Bangladesh)

\section{POSTER SESSION}

$7755 \mathrm{ON}$ Thermal characterization of nano $\mathrm{ZnO}$ incorporated natural rubber latex [7755-22] R. Kumar B., S. Basheer N., Catholicate College (India); A. Santhi, Cochin Univ. of Science \& Technology (India); A. Kurian, Catholicate College (India); S. D. George, Technische Univ. Darmstadt (Germany)

775500 Experimental observation and numerical simulation of the Lave diffraction in one-dimensional photonic crystals [7755-23]

S. E. Svyakhovskiy, A. I. Maydykovskiy, O. A. Aktsipetrov, Moscow State Univ. (Russian Federation)

$77550 Q \quad$ Preparation and investigation of diamond-like carbon nanocomposite thin films for nanophotonics [7755-25]

Zh. Panosyan, A. Gharibyan, State Engineering Univ. of Armenia (Armenia); A. Sargsyan, Armenian National Academy of Sciences (Armenia); H. Panosyan, BIPI Firm LLC (Armenia); D. Hayrapetyan, State Engineering Univ. of Armenia (Armenia) and Russian-Armenian (Slavonic) Univ. (Armenia); Y. Yengibaryan, State Engineering Univ. of Armenia (Armenia)

Author Index 


\title{
Conference Committee
}

\author{
Symposium Chairs
}

David L. Andrews, University of East Anglia Norwich (United Kingdom) James G. Grote, Air Force Research Laboratory (United States)

Conference Chairs

Stefano Cabrini, Lawrence Berkeley National Laboratory (United States)

Taleb Mokari, Ben-Gurion University of the Negev (Israel)

Program Committee

David L. Andrews, University of East Anglia Norwich (United Kingdom)

Angus J. Bain, University College London (United Kingdom)

Mireille H. Blanchard-Desce, Université de Rennes 1 (France)

Robert W. Boyd, University of Rochester (United States)

Zeno Gaburro, Università degli Studi di Trento (Italy)

Aaron W. Harper, The University of Southern California (United States)

Ghassan E. Jabbour, Arizona State University (United States)

François Kajzar, Université d'Angers (France)

Dmitri I. Kovalev, University of Bath (United Kingdom)

Paras N. Prasad, University at Buffalo (United States)

Dmitri Talapin, The University of Chicago (United States)

Younan Xia, Washington University in St. Louis (United States)

\section{Session Chairs}

1 Influence of the Shape and the Dopants on the Properties of Nanostructures

Stefano Cabrini, Lawrence Berkeley National Laboratory (United States)

2 Optical Properties of Nanostructures

Peter James Schuck, Lawrence Berkeley National Laboratory (United States)

3 Controlling the Optical Properties of Nanostructures by Forming Ternary Materials (Doping and Alloying)

Stefano Cabrini, Lawrence Berkeley National Laboratory (United States)

4 Charge Dynamics in Nanostructures

Xiaogan Liang, Lawrence Berkeley National Laboratory (United States) 
Downloaded From: https://www.spiedigitallibrary.org/conference-proceedings-of-spie on 26 Apr 2023

Terms of Use: https://www.spiedigitallibrary.org/terms-of-use 